\title{
Increasing the awareness of palm oil plantation replanting through farmers training
}

\author{
Almasdi Syahza (iD)*1, Djaimi Bakce (iD) 2, Brilliant Asmit (D) 1 \\ ${ }^{1}$ Faculty of Teachers Training and Education, Universitas Riau \\ ${ }^{2}$ Faculty of Agriculture, Universitas Riau \\ *almasdi.syahza@lecturer.unri.ac.id
}

\begin{abstract}
Palm oil plantation in the Province of Riau has reached the unproductive age and need replanting. Private and government-owned plantation has started the replanting, but plantation community owned. The slow replanting process in smallholders' palm oil plantation caused by poor knowledge of replanting. This community service objective was to increase the awareness of replanting of palm oil plantation run by smallholders, so it can accelerate the replanting process. We used interactive training method to deliver knowledge related to palm oil plantation replanting. The activity combined indoor and field class to give a better understanding of replanting. The community service activity involved academicians, palm oil practitioners, government institution, and palm oil farmers association. The success of this activity measured by the participant's assessment results through the written test. This training successfully delivered the needed knowledge and experience about palm oil plantation replanting. The knowledge and awareness were expected to accelerate the successful replanting process of palm oil plantation in the Province of Riau.
\end{abstract}

\begin{abstract}
Absrak Perkebunan kelapa sawit di Provinsi Riau telah mencapai usia tidak produktif dan perlu ditanam kembali. Perkebunan swasta dan milik pemerintah telah memulai peremajaan, kecuali perkebunan milik masyarakat. Proses peremajaan yang lambat di perkebunan kelapa sawit milik masyarakat disebabkan oleh kurangnya pengetahuan tentang peremajaan si pemilik. Tujuan kegiatan pengabdian kepada masyarakat ini adalah untuk meningkatkan kesadaran akan peremajaan kebun kelapa sawit yang diusahakan oleh masyarakat petani, sehingga dapat mempercepat proses peremajaan. Kami menggunakan metode pelatihan interaktif untuk menyampaikan pengetahuan terkait dengan peremajaan kebun kelapa sawit. Kegiatan ini menggabungkan metode pembelajaran di kelas dan lapangan untuk memberikan pemahaman yang lebih baik tentang peremajaan. Kegiatan pengabdian kepada masyarakat melibatkan akademisi, praktisi kelapa sawit, pemerintah, dan asosiasi petani kelapa sawit. Keberhasilan kegiatan ini diukur dengan hasil penilaian peserta melalui tes tertulis. Pelatihan ini berhasil memberikan pengetahuan dan pengalaman yang dibutuhkan tentang peremajaan perkebunan kelapa sawit kepada para petani. Pengetahuan dan kesadaran tersebut diharapkan dapat berkontribusi mempercepat proses peremajaan perkebunan kelapa sawit yang sukses di Provinsi Riau.
\end{abstract}

Keywords: palm oil; farmer; replanting; awareness; training

\section{ठ OPEN ACCESS}

Citation: Syahza, A., D. Bakce, and B. Asmit. 2018. Increasing the awareness of palm oil plantation replanting through farmers training. Riau Journal of Empowerment 1(1): 1-9 https://doi.org/10.31258/raje.1.1.1

Received: 2018-05-06, Revised: 2018-06-01, Accepted: 2018-06-21

Language: English (en)

Funding: This community services activity was funded by Badan Pengelola Dana Perkebunan Kelapa Sawit

๑) 2018 Syahza et al. The article by Author(s) is licensed under a Creative Commons Attribution 4.0 International License. This license permits unrestricted use, distribution, and reproduction in any medium, provided the original author and source are credited. 


\section{INTRODUCTION}

Province of Riau has superior plantation crops, one of which is palm oil. Palm oil of Riau cultivated since the 1980s since then the palm oil area has grown. By 2016, the planted area of palm oil is 2,425,138 ha and has been increased from 1,231,323 ha in 2004. The increased land area of palm oil plantation followed by increased production of fresh fruit bunches (FFB). According to Badan Pusat Statistik Provinsi Riau, in 2004, there were 3,327,419 tons of palm oil plantation production and by 2017 had produced 7,777,069 tons of palm oil fresh fruit bunch (FFB).

Palm oil crops can produce optimally until the age of 25 years. The development of palm oil plantations in the Province of Riau has been cultivated in the 1980s. Thus, many palm oil plantations that have been aged more than 25 years. It is the unproductive age for the crops, so it needs to be replanted. The palm oil areas planted in 1988 in Riau are 164,442 ha. The palm oil areas that predicted to be replanted in 2018 reaches 165,587 ha [8]. But in fact, the replanted area of palm oil plantation in Riau has not reached that number.

Farmer as the owner of palm oil plantation is the key factor to succeed palm oil replantation. As the owner, the farmers should quickly make a decision regarding the replantation of palm oil plantation. The successful palm oil farmer has the entrepreneurship characteristics, those are growth-oriented, risk taker, innovative, personal control, self-confident, and cooperative [2]. Farmers with these characteristics can make the right decision to manage their plantation. One of the important decisions should be made is plantation replanting. The farmers should have the courage, driven by growth-oriented, and risk taker characteristics to make this decision.

Syahza [7] suggests an institutional model for palm oil plantation. The model involves government, developers, financial institutions, and the farmer cooperatives to develop the rural economic trough palm oil plantation. The model is suitable with the Indonesian government program which is to develop palm oil as the national strategic commodity. Badan Pengelola Dana Perkebunan (BPDP) Kelapa Sawit as the government institution has role in managing palm oil fund in Indonesia to fulfil the program's objective. The collaboration of farmers, government, developer, and the financial institution will succeed the prosperity of palm oil community.

The academician can contribute to accelerating palm oil replanting through community service. We believe collaboration between government, academician, and business will give the significant impact for accelerating palm oil plantation owned by smallholders. We choose community services in the form of training for palm oil farmers. The objective of this training activity is to increase the awareness of palm oil farmers and to provide them with the knowledge about palm oil plantation replanting. So, they can manage their plantation replanting and accelerate palm oil replanting in Riau. In the next part, the paper will describe the problems of plantation replanting.

\section{PROBLEMS}

Based on the introduction part, we identify the main problem is the smallholders of palm oil plantation is reluctant to do replanting. This is because of some reasons such as uncertainty of household's economics, palm oil environmental issue, and poor knowledge in replanting best practice.

Indonesian palm oil smallholders face the negative issue of unfriendly environment management of palm oil cultivation. Limited area for developing palm oil plantation motivated the farmers to utilize peatland area. Afriyanti et al. [1] see the palm oil plantation is still promising without deforestation and peat conversion. Irianti et al. [3] find the erosion of the upstream of the Siak watershed is high because palm oil plantation management and soil conservation techniques do not follow the conservation principles. To overcome this issue, the Indonesia palm oil plantation manages their plantation based on Indonesian Sustainable Palm Oil (ISPO). ISPO will also apply on the next replanted plantation in Riau and it requires the smallholders of palm oil plantation to understand and willingness to apply the practice of 
sustainable palm oil. This service activity will increase the awareness of the community about more environmentally friendly plantation activities.

During replanting activity, the farmers will encounter risks, such as financial uncertainty, farming failure, pest attack on young crops, and temporary income before harvesting. Recognize the risks of replanting activity is fundamental. The risk recognition is the way to gain information about replanting best practice. The process of replanting needs to be done with the right knowledge and technology to fulfil the expected result. Therefore, a training in palm oil replanting is very important to be done. Replanting is used to obtain optimal production and provide maximum benefits for palm oil farmers. Having little knowledge and lack of information about replanting made the farmers difficult to make decisions. Training will help palm oil plantation smallholders to upgrade their skills [6] and knowledge [4] in running their plantation and overcome the risk.

Funding the replanting activity and establish new partnership are other problems in farmers side. There is an opportunity to be funded by the government through Badan Pengelola Dana Perkebunan (BPDP) Kelapa Sawit. This institution offers the replanting aid to palm oil plantation smallholders, and of course, there are some requirements to be fulfilled to get the fund. Not only the requirements from BPDP Kelapa Sawit should be fulfilled, but also the knowledge of Banking activity will be useful for the farmers. The requirements can be informed by the socialization of related institution in training activity.

Palm oil plantation smallholders need to establish new partnership pattern with the private sector. Replanting offers new opportunity to rebuild the cooperation between palm oil mills and plantation smallholders. Palm oil plantation smallholders hope the partnership provides the advantages to both parties.

Through community service activity the method of interactive training is the solution. This method will be further discussed in the next part of this paper.

\section{METHOD}

\section{Palm Oil Farmers Training}

The identified problems came from the lack of knowledge about replanting. The suitable method for the problems is informal education, that is, training. According to Saifullah et al. [6], training will help palm oil plantation smallholders to upgrade their farming skills. The educational approach suggested by Ndungi et al. [4] will increase their awareness about the information and knowledge that has been delivered. We organized interactive training for palm oil farmers. The focus of training is to empower palm oil farmers by increasing the awareness of replanting. We build their awareness by delivering a complete knowledge of palm oil plantation replanting.

Training is designed to deliver knowledge needed by palm oil farmers related to replanting issue. The materials are delivered in the class by palm oil experts as the tutors. The tutors are academicians and researchers group from Universitas Riau, Indonesian Palm oil Research Institute (PPKS), and Asian Agri Oil Palm Research Station (OPRS) Topaz; regulators from Plantation Services of Riau Province Government and Badan Pengelola Dana Perkebunan (BPDP) Kelapa Sawit; the practitioners group from PT Perkebunan Nusantara V (PTPN V) Province of Riau, Asosiasi Petani Kelapa Sawit Perusahaan Inti Rakyat (ASPEKPIR), Cooperative of Mulus Rahayu, and Cooperative of Tunas Jaya; and also, banking institution from PT Bank Rakyat Indonesia, PT Bank Negara Indonesia, and PT Bank Riau Kepri. The tutors lecture replanting materials in 13 modules. These modules are designed to fulfil the objective of this community services activity. The modules are listed in Table 1.

In Table 1, we can see that the training class is held in 40 study hours or equal to 5 days ( 8 study hours per day). The materials are presented in 2 sessions, there are interactive learning session and field class session. Lecture session is presented in an indoor class by tutor groups for 24 study hours, and field class session for 16 study hours delivered by the group of practitioners. 
Table 1. Replanting modules in the training of palm oil farmers

\begin{tabular}{|c|c|c|c|}
\hline No. & Modules & Tutor Group & Study Hours \\
\hline 1 & $\begin{array}{l}\text { Role and Function of BPDP Kelapa Sawit in the } \\
\text { Replanting of Palm oil Plantation }\end{array}$ & $\begin{array}{l}\text { Regulators/Local } \\
\text { Government }\end{array}$ & 2 \\
\hline 2 & Model and Problems of Palm oil Replanting & $\begin{array}{l}\text { Academicians and } \\
\text { Regulators }\end{array}$ & 2 \\
\hline 3 & $\begin{array}{l}\text { Principles and Criteria in the Application of } \\
\text { Indonesian Sustainability Palm Oil (ISPO) }\end{array}$ & Academicians & 3 \\
\hline 4 & Building Cooperation and Group Dynamics & Academicians & 2 \\
\hline 5 & Management of Land Suitability & Academicians & 2 \\
\hline 6 & Land Preparation & Practitioners & 2 \\
\hline 7 & Nurseries & Practitioners & 2 \\
\hline 8 & Management of Legume Cover Crops (LCC) & Practitioners & 2 \\
\hline 9 & Plant and Planting Preparation & Practitioners & 2 \\
\hline 10 & Plant Maintenance & Practitioners & 2 \\
\hline 11 & Best Practices Replanting & Practitioners & 2 \\
\hline 12 & $\begin{array}{l}\text { Scheme of Plantation Financing through } \\
\text { Banking }\end{array}$ & Banking & 2 \\
\hline 13 & Field Class & Practitioners & 16 \\
\hline \multicolumn{3}{|c|}{ Total } & 40 \\
\hline
\end{tabular}

Field classes are held in the palm oil plantation area owned by PT Perkebunan Nusantara V, Kampar; Asian Agri OPRS Topaz, Kampar; and community plantation of Cooperative of Tunas Jaya, Siak. The field class led by instructors in each plantation.

The training is held in 9 classes and the participants are from 7 regencies of palm oil producer in Riau. The regencies are Indragiri Hulu, Kuantan Singingi, Rokan Hulu, Rokan Hilir, Kampar, Siak, and Pelalawan.

\section{Participant Recruitment}

The training designed for 50 participants in each class. We collaborated with ASPEKPIR, as the partner committee in palm oil farmers training, to recruit the participants. As palm oil farmers association, ASPEKPIR has the database of palm oil farmers in Province of Riau. ASPEKPIR recruit participants from the representative of farmer group and cooperative in the regencies. This criterion of the participant will give positive impact to the result of training, which they have an important role to make decision in each community.

Important recruitment is the participants can read and write. We make sure all participants to fill the name, address, phone number, and sign the list of attendance by his/her self. Other recruitments are the participant reside in the Province of Riau and Indonesia citizen. The last requirement can be detected from his/her Indonesian ID card.

\section{Training Assessment}

The success of this activity depends on the involvement of participants. The attendance and participation in discussion are the assessment of successful training. The participants are required to sign absence at each training day.

Another tool used for training assessment is the pretest and posttest for participants. This tool helps to measure the participants' understanding concerning training materials both in lecture and field sessions. The pretest is required to be done by each participant at the beginning of training. And in the end, they are required to do the posttest. The questions in pretest and posttest are the same, so we can assess the participants' understanding of the training material. 
The questions of the test are made simple, and we only give the question of the basic knowledge of the material delivered by tutors. In total, from 13 modules the participants should answer the 21 questions. The simple questions are made by considering the education level and the age of the participants. To analyze the result and for better understanding, we convert the score for right answers to 0-100 scales. Each right answer will be 100 divided to 21 questions, and it is 4.76 per correct answer.

\section{Location and Time}

All the 9 training classes held in the City of Pekanbaru, Riau, Indonesia during September 2016 - March 2017. The reasons to choose this location are:

- Access to location. The capital city of Riau Province has easy access from/to any location in the province. It includes participants regencies and field class locations.

- Accommodation facilities. Training is held in the hotel with full facilities for 5 days of training. This includes room and consumption for participants. The accommodation also provides audio-visual technology which is useful for the quality of lecturing session in class.

- Full participation. Far away from their village ensures the participants pay full attention to participate in the training. They will participate without disturbance of their personal business at the village during training.

The palm oil farmers training is held in 9 classes, which the schedule can be seen in Table 2 .

Table 2. Schedule of palm oil farmers training classes

\begin{tabular}{cccc}
\hline Class Name & Date & Recency & Participants (person) \\
\hline IHU01 & 5-9 September 2016 & Indragiri Hulu & 50 \\
KNS01 & 19-23 September 2016 & Kuantan Singingi & 50 \\
RHU01 & 26-3 September 2016 & Rokan Hulu & 50 \\
SAK01 & 3-7 October 2016 & Siak & 50 \\
IHU02 & 10-14 October 2016 & Indragiri Hulu & 50 \\
PLW01 & 17-21 October 2016 & Pelalawan & 50 \\
KPR01 & 22-26 February 2017 & Kampar & 50 \\
RHI01 & 16-20 March 2017 & Rokan Hilir & 50 \\
PLW02 & 27-31 March 2017 & Pelalawan & 50 \\
\hline
\end{tabular}

\section{DISCUSSION}

The training activity provides a complete solution for replanting preparation. It increases palm oil farmers' awareness of replanting. Here's the discussion of the community service activity.

\section{Knowledge Transfer}

The main activity of training is transferring the knowledge to participants. We focus on delivering applicable information on palm oil plantation replanting. The activity held in 40 study hours presented in 13 modules. Most of the modules deliver in the class through interactive learning method. The interactive learning method can be seen in Figure 1.

The field class module is spent in the field by visiting palm oil plantation, cooperatives, and palm oil mills. In the discussion, the paper will divide the modules into 3 categories as follows: palm oil policy, partnership and financing, and best practice. 

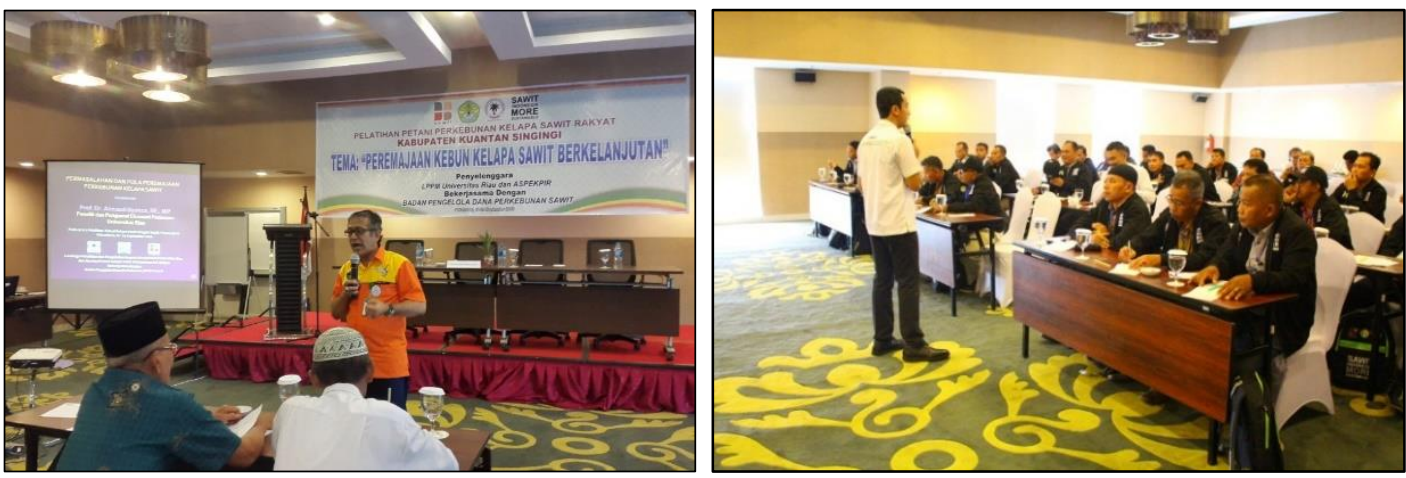

Figure 1. Tutors deliver the material of palm oil plantation replanting in the class

\section{Palm Oil Policy}

The modules related to policy explain the future challenge of palm oil plantation such as palm oil price and market, plantation competitiveness, and environmental issues. There are 2 modules categorized as palm oil policy, namely Role and Function of BPDP Kelapa Sawit in the Replanting of Palm Oil Plantation, and module Principles and Criteria in the Application of Indonesian Sustainability Palm Oil (ISPO).

Through the activity the tutor socializes the role of government institute of palm oil, it is BPDP Kelapa Sawit. This module delivers the understanding and the existence of BPDP Kelapa Sawit. This module describes the role in developing palm oil plantation in Indonesia and the effort to strengthen the Indonesian palm oil market share in global. Other important information for participants is that BPDP Kelapa Sawit is the institute which is managing the aid for palm oil replanting. The module is delivered by BPDP Kelapa Sawit itself, so the participant got much information about the application requirements for palm oil replanting aid.

Another module delivered the policy of environmental issue. The Indonesia government proclaims the sustainable palm oil plantation through ISPO. ISPO is mandatory for palm oil plantation in Indonesia. ISPO is an Indonesian effort to encounter negative campaign of poor environmental management in running the palm oil plantation. This module presented the sustainable palm oil plantation principles and criteria. So, the farmers and their group could plan their sustainable plantation for replanting.

\section{Partnership and financing}

Replanting can be the opportunity to establish a new partnership between smallholders' palm oil plantation and the palm oil enterprise such as palm oil mills. This training material is well presented in the module Model and Problems of Palm Oil Replanting. This knowledge is important for participants considering they must decide about what partnership model for the next plantation period. This module provided the participants with plenty idea of the partnership model. The participants are expected to develop their partnership model with their group. With the learned knowledge of partnership models, the smallholders can establish the advantageous partnership model between their group and the enterprise.

To support the module of the partnership model, we add the module of farmer group empowerment. The objective of this module is to encourage the participants to get involved with their farmer group or cooperatives. By empowering the farmers within their group and cooperative makes the palm oil replanting is achievable. The replanting activity involves many palm oil smallholders in an area. Unification of mind within farmers group is another challenge because there are many personal interests. This module motivated the participants to get involved within their group and unify their ideas and vision to come forward.

The module of financing aims to increase the participant's awareness of banking. Supported by finance institute like Bank is the government requirement of distributing the replanting aid to the farmers. This module was presented by banking practitioner. After learning the module, the participants are expected to understand about banking administration, so the farmers can be the bank-friendly persons and able to propose replanting aid to the BPDP Kelapa Sawit. 


\section{Technical and Best Practice}

Syahza et al.

From the total 13 modules delivered to participants, most of it is technical knowledge of palm oil replanting. These modules give major knowledge of replanting process specifically management of land suitability, land preparation, nurseries, management of Legume Cover Crops (LCC), plant preparation, planting preparation, and plant maintenance. The materials are well presented by mostly technical practitioners and academicians.
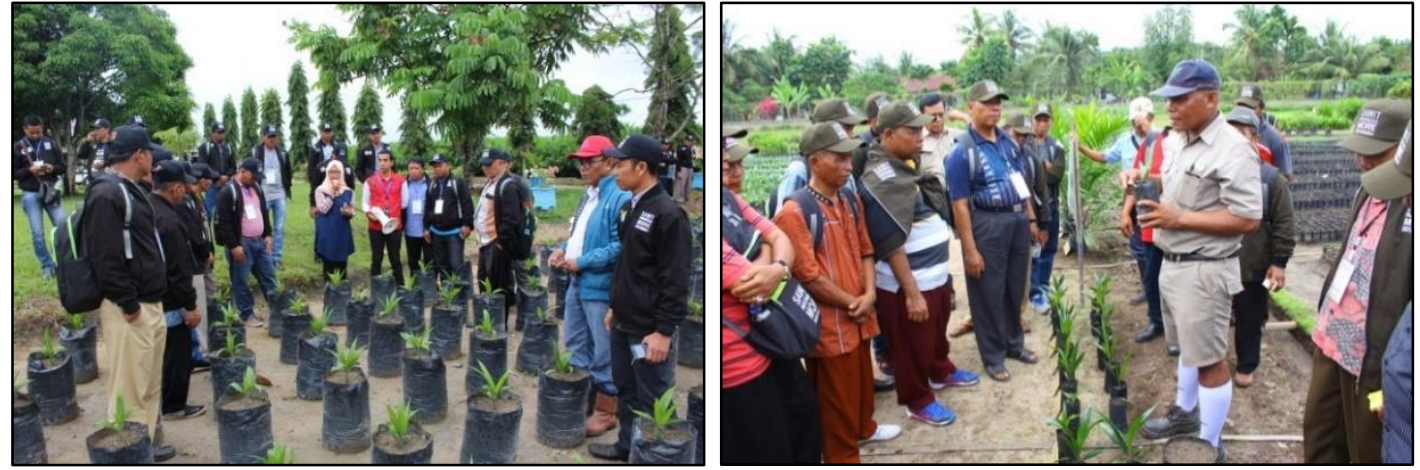

Figure 2. Participants discuss oil palm nursery with the tutors
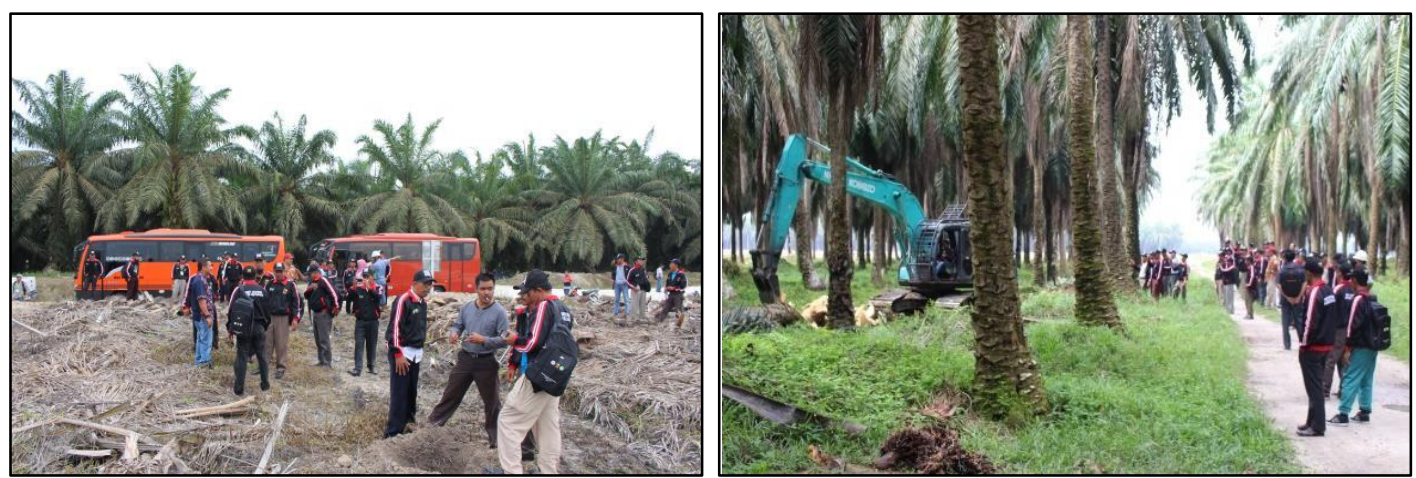

Figure 3 Training participants see the activities of land preparation for palm oil plantation replanting

Not only the theory presented in the indoor class, the training also gave field experience to the participants. Field class aims full understanding and close experience of palm oil replanting process to the participants. In the field class, participants were brought to the plantation replanting area, nursery unit, palm oil cooperatives, and palm oil research centre. Thanks to the PT Perkebunan Nusantara V and OPRS Topaz for tutoring the field class. The documentation of field class can be seen in the Figure 2, 3, 4, and 5.

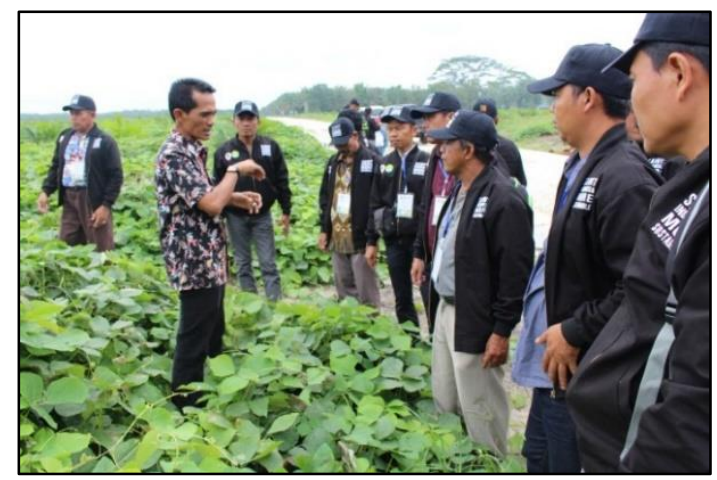

Figure 4. Field tutor explains how to maintain Legume Cover Crops (LCC) 

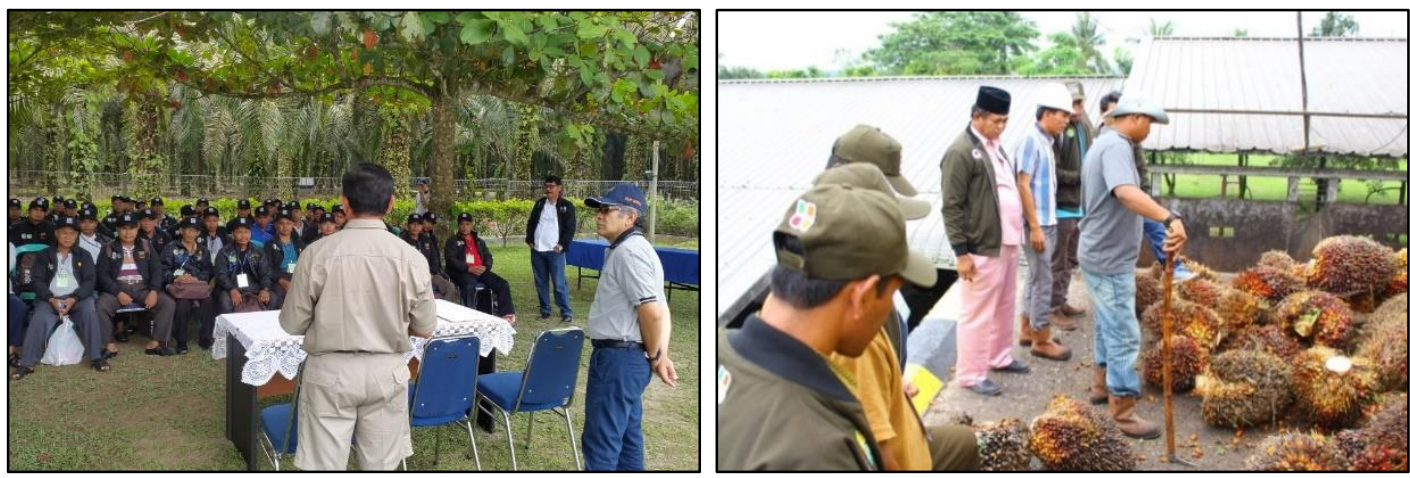

Figure 5. Participants visit palm oil mills and discuss a possible partnership with the enterprise

\section{Assessment Test Result}

The average pretest of 9 training classes is 38.03 , and posttest score is 86.34 . The lowest posttest score is Rokan Hilir Class (RHI01) 80.48, and Indragiri Hulu (IHU01) has the highest score for posttest, it is 90.48. The complete result of all classes is provided in Figure 6 .

From the assessment result, the participants in the training have learned and understood the materials delivered by tutors. The participants in pretest could only answer 8 questions correctly, compared with posttest result they can answer 18 questions on average from a total of 21 questions. The knowledge of the participants from the beginning of training has been increased. Knowledge and awareness are crucial factors and can provide huge opportunities in any field [5]. Giving knowledge of palm oil plantation replanting as information needed to accelerate the replanting decision making.

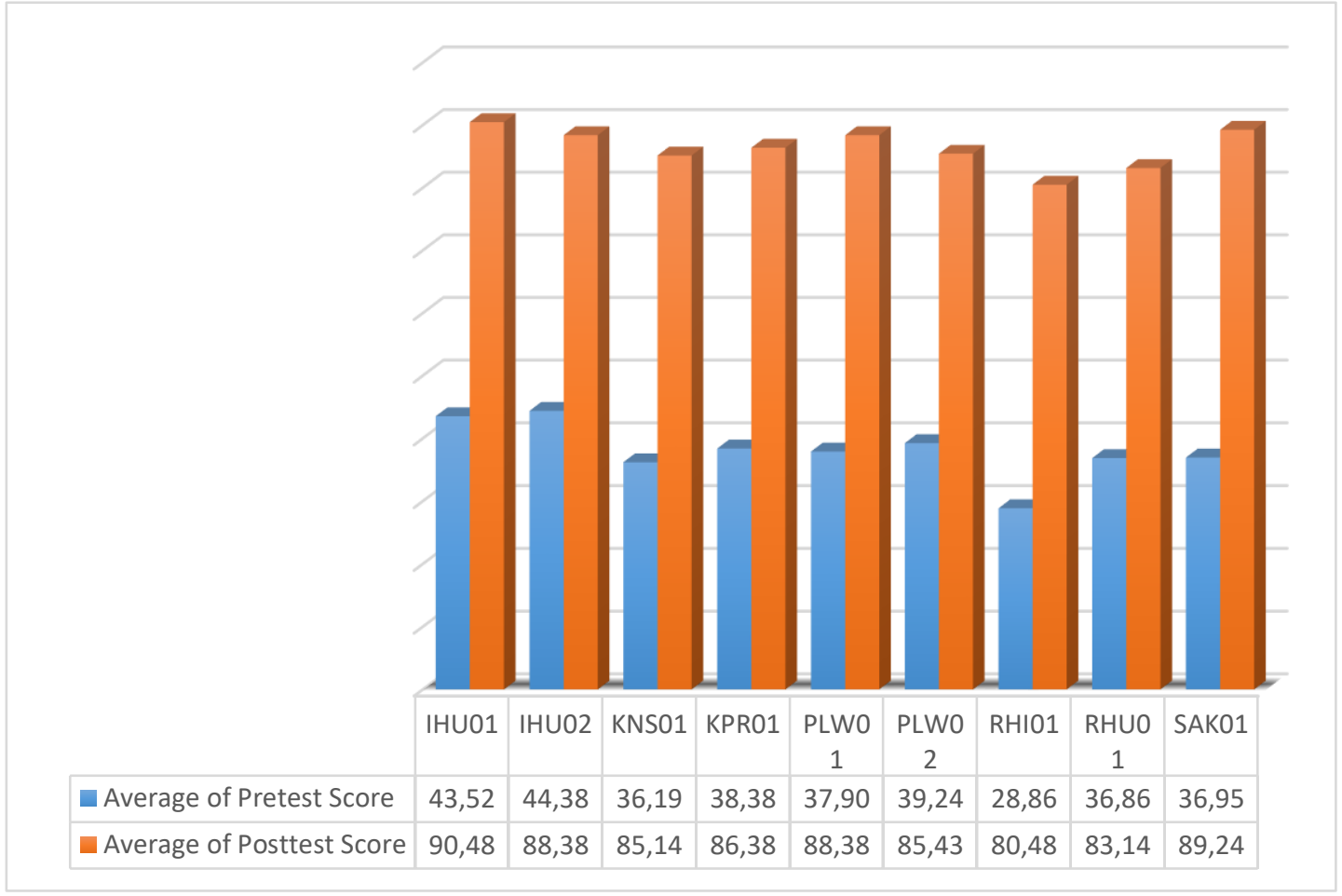

Figure 6. Participants' assessment result

\section{CONCLUSION}

Informal education in short class as the used method has fulfilled the objective of this community service. Through the training, the palm oil plantation smallholders increase their knowledge of plantation replanting and increases their awareness about replanting. The training combines in class learning and field experience. It is not delivered by academicians 
only, but also palm oil field expert. This method makes farmers more understand the material that has been taught. The knowledge about palm oil plantation replanting can overcome the risks related to replanting. This achievement will be the first step to plan and execute the replanting activity.

To continue the result of this community service, we suggest other opportunities for the next community service, there is the assistance of plantation replanting activity, and of course, it will involve many parties. This activity will be better if followed by other training for plantation smallholders such as increasing palm oil plantation productivity and establish sustainable palm oil plantation.

\section{ACKNOWLEDGEMENT}

Authors would like to thank Badan Pengelola Dana Perkebunan (BPDP) Kelapa Sawit for funding the community service activity, and Asosiasi Petani Kelapa Sawit Perusahaan Inti Rakyat (ASPEKPIR) Provinsi Riau as the partner committee. We also thanks to the experts and tutors from Faculty of Agriculture Universitas Riau, PT Perkebunan Nusantara V (PTPN V), Asian Agri Oil Palm Research Station (OPRS) Topaz, KUD Mulus Rahayu, KUD Tunas Jaya, Indonesian Palm Oil Research Institute (PPKS), Dinas Tanaman Pangan Hortikultura dan Perkebunan Provinsi Riau, PT Bank Rakyat Indonesia, PT Bank Negara Indonesia, and PT Bank Riau Kepri, for delivering valuable knowledge to the palm oil smallholders.

\section{References}

1. Afriyanti, D., C. Kroeze, and A. Saad. 2016. Indonesia palm oil production without deforestation and peat conversion by 2050. Science of The Total Environment, 557-558, pp.562-570. https://doi.org/10.1016/j.scitotenv.2016.03.032

2. Asmit, B. and D.P. Koesrindartoto. 2015. Identifying the Entrepreneurship Characteristics of the Oil Palm Community Plantation Farmers in the Riau Area. Gadjah Mada International Journal of Business, 17(3), pp.219-236. https://doi.org/10.22146/gamaijb.8500

3. Irianti, M., B. Nasrul, and B. Asmit. 2016. Kajian Tingkat Bahaya Erosi dan Pengendaliannya di Daerah Aliran Sungai Siak Bagian Hulu. In: Seminar Nasional "Pelestarian Lingkungan \& Mitigasi Bencana”. [online] Pekanbaru: Program Studi Ilmu Lingkungan Program Pascasarjana Universitas Riau, pp.31-36.

https://repository.unri.ac.id/xmlui/bitstream/handle/123456789/8580/R1.5Mitri\%20Iriantimakalah\%20semnaslingk\%202016.pdf?sequence=1\&isAllowed=y Accessed 25 April 2018.

4. Ndungi, F.N., P. Tuitoek, dan A.A. Aboud. 2017. Socio-Economic Status, Knowledge, Awareness and Attitudes of the Swahili Community in Relation to Dietary Habits, Obesity and Lifestyle Diseases. African Journal of Food, Agriculture, Nutrition and Development, 17(1), pp.11709-11725. https://doi.org/10.18697/ajfand.77.16335

5. Raghuvanshi, M. 2016. Knowledge and Awareness: Linear Regression. Educational Process: International Journal, 5(4), pp.279-292. https://doi.org/10.1108/IJSE-10-2016-0296

6. Saifullah, M.K., F.B. Kari, and A. Othman. 2018. Poverty among the small-scale plantation holders indigenous communities in peninsular Malaysia. International Journal of Social Economics, 45(2), pp.230-245. https://doi.org/10.1108/IJSE-10-2016-0296

7. Syahza, A. 2012. The Institutional Arrangements in the Palm Oil Sector: Effort to Spur Economic Growth in Rural Areas. International Research Journal of Business Studies, 4(3), pp.171-188. https://doi.org/10.21632/irjbs.4.3.171-188

8. Syahza, A., Suwondo, D. Bakce, F.H. Ernaputra, and R.M. Riadi. 2013. Kegiatan Tindak Lanjut Penghimpunan Data, Informasi Dana Bagi Hasil (DBH) Sektor Perkebunan (DBH CPO). Pekanbaru: Lembaga Penelitian Universitas Riau. 